\title{
A Golden Calendar from the Bronze Age
}

\author{
Nils-Axel Mörner ${ }^{1}$, Bob G. Lind ${ }^{2}$, Göran Henriksson ${ }^{3}$ \\ ${ }^{1}$ Institute of Paleogeophysics \& Geodynamics, Stockholm, Sweden \\ ${ }^{2}$ Archaeoastronomy, Malmö, Sweden \\ ${ }^{3}$ Departmeny of Physics and Astronomy, Uppsala University, Uppsala, Sweden \\ Email: *morner@pog.nu
}

How to cite this paper: Mörner, N.-A., Lind, B. G., \& Henriksson, G. (2018). A Golden Calendar from the Bronze Age. Archaeological Discovery, 6, 53-61. https://doi.org/10.4236/ad.2018.62004

Received: February 27, 2018

Accepted: March 30, 2018

Published: April 2, 2018

Copyright (C) 2018 by authors and Scientific Research Publishing Inc. This work is licensed under the Creative Commons Attribution International License (CC BY 4.0).

http://creativecommons.org/licenses/by/4.0/

(c) (7) Open Access

\begin{abstract}
A golden object found in southern Sweden 170 years ago is found, in fact, to be an ancient calendar. The golden object is ornamented with 12 sun-symbols and 12 moon-symbols; i.e. a combined picture of the annual movements of the Sun and the Moon through the sky. It is divided into 6 wedges by spoke structures. This is a representation of the Sumerian sexagesimal system. Similar images are present in rock-carvings in Sweden, and on a stone tablet from the ancient temple in Sippar in Mesopotamia. This gives evidence of a remarkably advanced knowledge in astronomy and a wide distribution of this knowledge from Mesopotamia all the way up to Scandinavia.
\end{abstract}

\section{Keywords}

Golden Calendar, Sun Cult, Rock-Carving, Sexagesimal System, Bronze Age, Sweden

\section{Introduction}

In 1847, a golden bowl was found in a peat bog in southern Sweden. An age of about $1000 \mathrm{BC}$ was assigned. For 170 years it was believed to be just a bowl, though of gold and with ornaments typical for the Bronze Age. Last year, we turned it up-side-down and were struck by a totally new finding: it is a golden sky dome calendar.

This called for an extensive analysis of the cultural and astronomical background of the sky dome calendar. Figure 1 gives the location of the ten sites discussed in the text.

\section{The Golden Calendar from Mjövik}

In a peat bog in southeastern Sweden (the County of Blekinge, Parish of Nättraby and area of Mjövik) a golden object was found in 1847 (Figure 1, site 1). 


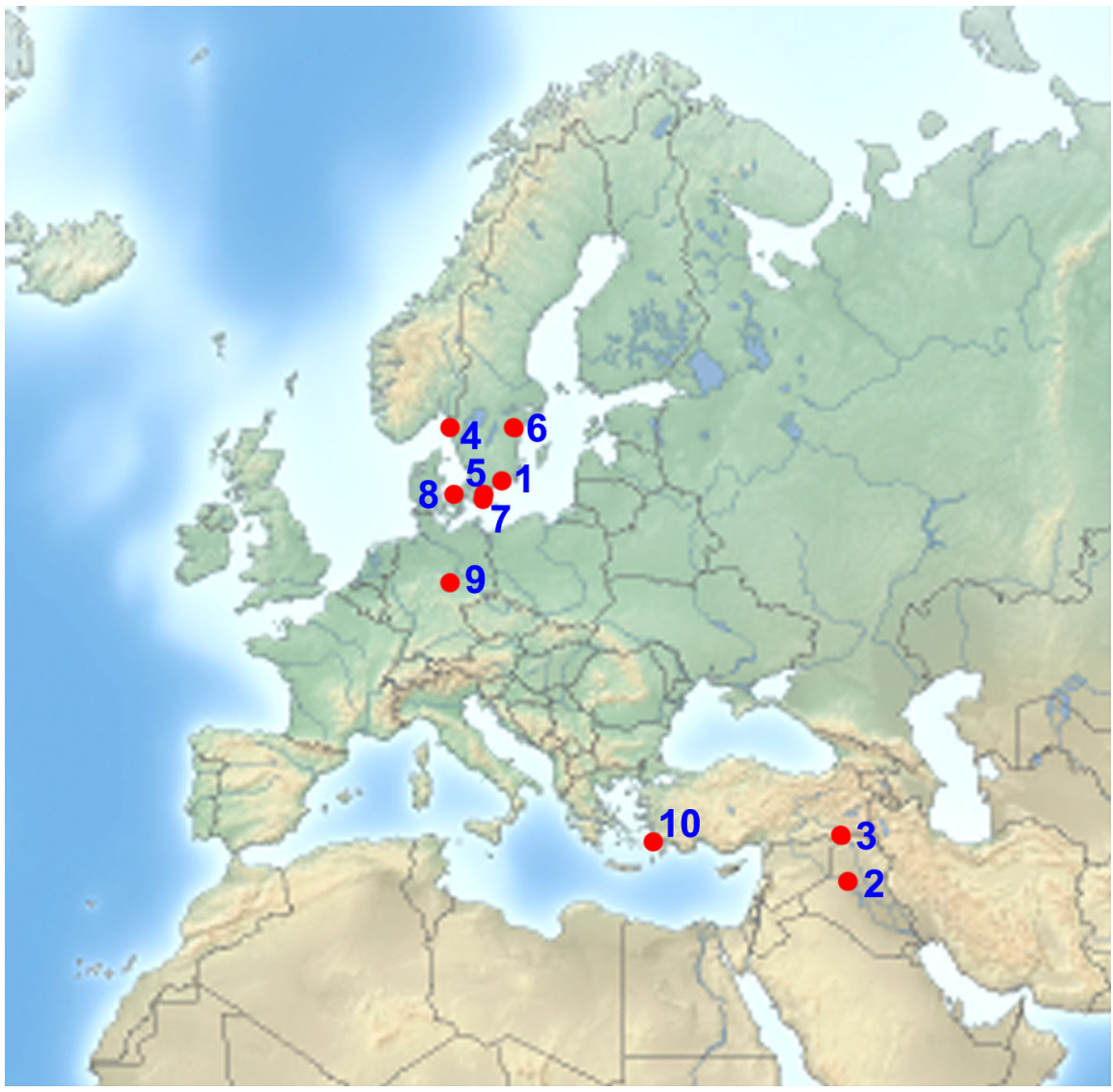

Figure 1. Location of sites discussed. 1: Mjövik with the discovery of the golden Sky Dome Calendar here presented (Figures 2-3). 2: The Ancient City of Sippar with its famous Sun temple with its Sun and Moon altars (Figure 4). 3: Nineveh with the inscription here discussed. 4: Backa in Brastad rock-carving with it image of a Sun with 6 spokes (Figure 5). 5: the trading centre in the Ravlunda-Kivik area. 6: Rock-carvings with images of stellar constellations and calendar ships. 7: The Ales Stone, a remarkable astronomical calendar in the form of a $69 \mathrm{~m}$ long stone ship. 8: Trundholm where the Sun Chariot was found. 9: Location of the discovery of the Nebra Sky Disk. 10: Ulu Burun with the discovery of an ancient cargo ship. The solar-lunar astronomy developed by the Sumerians and Babylonians spread rapidly over the Middle East and Europe in the Early Bronze Age. Sites 1, 2 and 4 are the main sites in this paper. Sites 3, 5 and 10 are indicative of active long-distance travel and trading.

It was classified as an urn, and came to be known as "the Blekinge golden urn" or "Nättraby golden urn". It is now kept in the "gold-room" of the Swedish Historical Museum (SHM, no. 1426; SHM, 2017).

The "urn" has an ornamentation typical of Bronze Age objects, and was assigned an age of about $1000 \mathrm{BC}$. It consists of leaf-thin gold with pressed ornamentation. It has a diameter of about $20 \mathrm{~cm}$.

For 170 years it has been interpreted as an urn or bowl (Figure 2(a)). In 2017, we suddenly saw a totally new interpretation when viewing the proposed bowl in an up-side-down position (Figure 2(c)). The trivial "urn" or "bowl" (though of gold) was, with a eureka experience found, in fact, to be a unique sky dome with sophisticated astronomical ornamentations. 


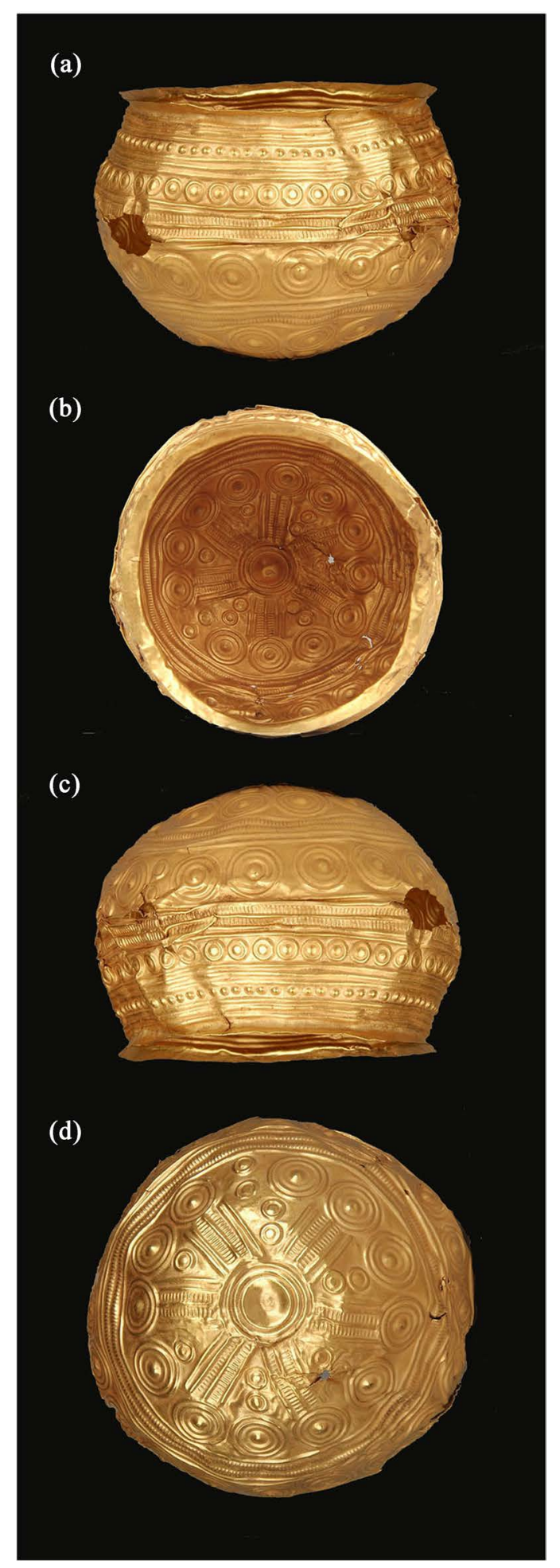

Figure 2. The golden sky dome calendar at Mjövik (redesigned from SHM, 2017). This object was found in 1847 and believed to be an urn or bowl. We turned it up-side-down and realized that it, in fact, was a sky dome. (a) In bowl or urn position, which the strongly concave bottom surface, in fact, contradicts; (b) View into the "urn" with a broad and flat edge, which prevents drinking and rather suggests that it should be standing on this edge; (c) In sky dome position with a basal edge to stand on; (d) View of the dome from above with its very interesting ornamentation. 
In Figure 2, the golden object is shown in four different positions ((a) to (d)). Position (a) shows the object in an urn or bowl position. The proposed bottom is strongly concave, however, which makes a stable urn or bowl position quite complicated or even impossible. Position (b) shows the urn, looking into it. The bent edge is $1 \mathrm{~cm}$ wide and quite flat, implying that it was designed as the base (not top) of the object. Besides, the bent edge prevents the use as a drinking bowl. Position (c) gives the correct view according to our interpretations; i.e. as a sky dome calendar. Position (d) gives the view of the top of the sky dome with the 6 spoke-bound wedges, 12 sun-symbols and 12 moon-symbols.

The ornamentation on the top of the sky dome calendar is of great significance (Figure 3). There is a central sun-symbol with 6 sunbeams or spokes going out to a circle of 12 sun-symbols. The 6 spokes divide the sky dome into 6 wedges. Within the first three wedges there are 2 moon-symbols per wedge (segment). In the $4^{\text {th }}$ and $5^{\text {th }}$ wedge there is only 1 moon-symbol per wedge. However, in the $6^{\text {th }}$ wedge there are 4 moon-symbols. This means that the calendar, in total, comprises 12 sun-symbols and 12 moon-symbols. Therefore, the Mjövik Sky Dome Calendar gives a remarkable image of the combined annual movements of the Sun and the Moon during 12 solar months ( 30.4 days) and 12 lunar months ( 29.5 days).

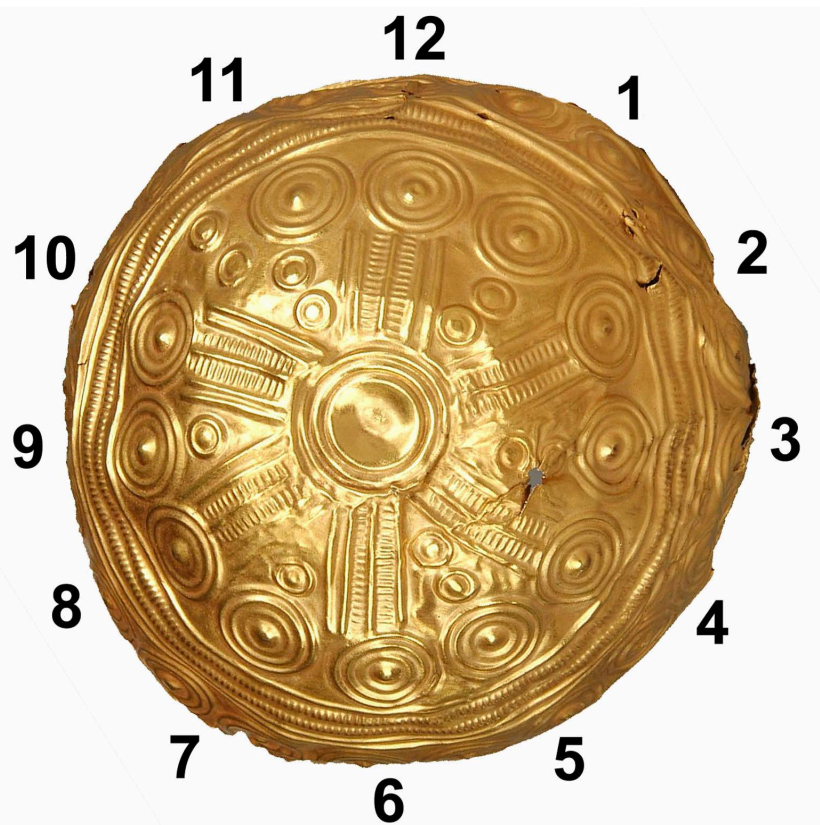

Figure 3. The golden calendar. The Sun, or rather Sun God, is in the centre and with six radial spokes or sunbeams going out to every second sun-symbol around the edge, making a calendar sun-wheel of 6 segments of 60 days (2 solar and lunar cycles) that is a year of 360 days (the leap days not included). This is a manifestation of the Sumerian-Babylonian sexagesimal system. The year consists of 12 solar months $(1-12)$ and 12 lunar months (with an irregular position in the six 60-days segments). 
Each of the 6 spoke-bound wedges represents 2 solar months of 30 days, in total giving a year of 360 days $(6 \times 60)$, with the extra leap year days added in July (as well documented in the Ales Stone astronomical monument in southeast Sweden; Lind, 2005; Mörner, 2015). The division into 6, 60, 360 implies the application of the sexagesimal system, a mathematical-astronomical system that originates from the Sumerian-Babylonian Culture in Mesopotamia (Ifrah, 1994).

\section{Ancient Sumerian Astronomy}

The oldest picture of the sky occurs on a cylinder seal (von der Osten, 1934) from the region just north of Bagdad. Due to the image of an eclipse, it can be dated at 3653 BC (Henriksson, 2017). The sexagesimal system is known to have originated with the Sumerians (Ifrah, 1994). Therefore, the Mjövik Sky Dome Calendar with its sexagesimal system must have had some cultural linkage with ancient Mesopotamia.

The Ancient City of Sippar (Figure 1, site 2) was an important Sumerian and Babylonian city (Sippar, 2017). There was a famous Sun Temple in the Ancient City of Sippar. On a stone tablet, there is an image of a Moon altar and a Sun altar in the Sun Temple (Figure 4) (Montelius, 1911). This image is central because it shows the close connection between the worshiping of the Sun and the Moon, both moving through the sky in rhythms giving 12 slightly different months making up a full year. In the original picture, a high priest is pointing at the sun-wheel. The sun-wheel is 6-spoked, just as the Mjövik Sky Dome Calendar, representing six double months of 60 days, in full accordance with their sexagesimal system.
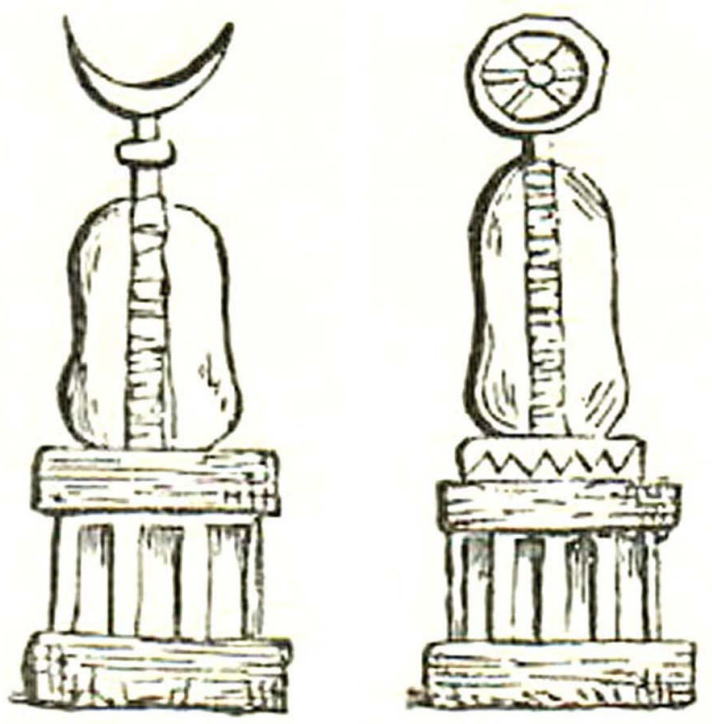

Figure 4. The Moon and the Sun altars in the Sun Temple in the Ancient City of Sippar (redesigned from Montelius, 1911). The Sumerians and Babylonians understood that both the Moon and the Sun played a central role in the annual cycles of the heavens. The Sun is shown as a 6-spoked disk, just as is the case with the Mjövik Calendar and the Backa rock-carving. It is a manifestation of the Sumerian-Babylonian sexagesimal system. 
In the search for cultural trading links to Europe and Scandinavia, it seems significant that, on an obelisk in Nineveh dated at about 1850 BC (Figure 1, site 3), the following text is found (Oppert, 1876; Rice, 1993; Lind \& Mörner, 2010): "on the sea of changing winds my merchants fish pears, and on the sea where the North Star culminates they fish yellow amber". The first sea must refer to the Gulf of Persia, and the second is likely to refer to the Baltic (because only there is the North Star high to the north, and the shores full of yellow amber; Lind \& Mörner, 2010).

\section{Sun Cult in Northern Europe}

At Backa in Brastad in the county of Bohuslän in southwest Sweden (Figure 1, site 4), there is an impressive rock-carving (Baltzer, 1911) with ships, men, animals and an important sun image (Figure 5, with sun image marked in red). The sun is carved as a 6-spoke wheel just as in the ornament on the Mjövik calendar (Figure 2) and the sun-symbol on the Sippar image (Figure 4). Together with another cosmological object, the sun-symbol is attached to two ships. Both ships are held by a deity moving the Sun through the sky.

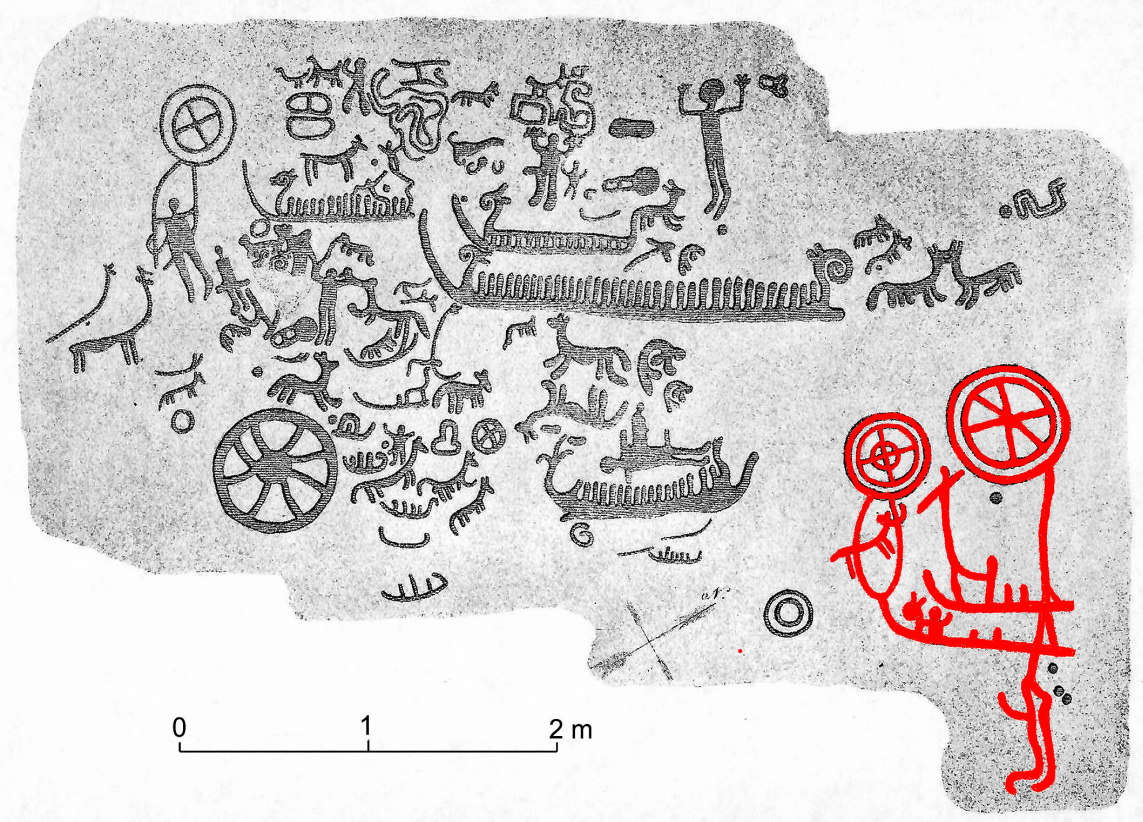

Figure 5. The rock-carving at Backa in Brastad in southwest Sweden (redrawn from Baltzer, 1911). This is a large rock-carving covering about $6.5 \times 4.0 \mathrm{~m}$. The picture of main interest is marked in red (which is the natural coloring of rock-carvings nowadays). It shows a Sun with 6 segments (spokes) just as the ornaments on the Mjövik Calendar (Figure 2-3) and the sun-altar in Sippar (Figure 4). The 6-spoke sun-symbol together with another cosmological object is attached to two ships moved through the sky by a deity. All together, there are 6 ships on the Backa rock-carving, all aligned in NE-SW implying that they are sailing from the sunrise at Summer Solstice to the sunset at Winter Solstice. The big ship in the middle is manned by 36 persons. The number of ships and the number of sailors seem to be another manifestation of the application of the sexagesimal system in this rock-carving. 
The cultural linkage between the Sun and Moon altars in the Sun Temple of Sippar (Figure 4), the Sun boat in the Backa in Brastad rock-carving (Figure 5) and the 6-spoke solar ornament on the Mjövik calendar seems obvious.

The Nineveh inscription (above) suggests that Sumerian merchants may have collected yellow amber in the Baltic as early as in about $1850 \mathrm{BC}$, if so, providing indication of active cultural interchange between Mesopotamia and the Baltic region already at the transition between the Neolithic and the Bronze Age of Scandinavia. In a number of papers, we have shown that people from the Eastern Mediterranean region established a trading centre in southeast Sweden (Figure 1, site 5) in about 1750 BC (Mörner \& Lind, 2010, 2013, 2015). They brought bronze into Sweden, initiating the Scandinavian Bronze Age (Mörner \& Lind, 2015). The proposed trading centre in the Ravlunda-Kivik area is just where yellow amber was accessible in large quantities (Figure 1, site 5). Significantly, amber started to occur in great quantities in Mycenaean and Minoan tombs from about 1600 BC (Lind \& Mörner, 2010; Mörner \& Lind, 2015). Three omega signs occur in southern Sweden (Mörner \& Lind, 2015). Obviously, they must owe their origin to Ancient Greece.

The Ales Stones are an impressive monument of 60 stones (today 59 left) in the form of a $69 \mathrm{~m}$ long stone-ship, precisely oriented with respect to the annual and daily movements of the Sun through the sky (Figure 1, site 7) (Lind, 2005; Mörner, 2015; Mörner \& Lind, 2012). This monument is an astronomical calendar and records 11 months of 30 days and a $12^{\text {th }}$ month (July) of 35 days, giving a full year of 365 days.

A calendar with six double months has been used on the Swedish rock-carvings (Figure 1, site 6) (Henriksson, 1999). The double months are represented as six differently shaped skips along the ecliptic, the suns path among the stars. The shapes of the ships depend on the position of the brightest stars in the area of the sky and are easily recognizable. Every ship corresponds to 60 days except the ship that begins with the Summer solstice, which has 65 or 66 days (Henriksson, 1999).

The Sun Cult played a central role during the Scandinavian Bronze Age (Montelius, 1911). Vivid examples are given in the Sun Chariot of Trundholm (Müller, 1903) and the Nebra Sky Disk (Welle, 2002) (Figure 1, sites 8 - 9).

In 1984, an ancient cargo ship was found at Ulu Burun off the Turkish coast (Figure 1, site 10) (Pulak, 1998; Lind \& Mörner, 2010; Mörner \& Lind, 2015). The ship is dated at $1315 \mathrm{BC}$. It had an interesting cargo from a variety of origins; viz 10 tons of copper from Cyprus, 1 ton of tin of uncertain origin, glass from Mycenae, ceramics from Cyprus, jewels from Egypt, perfume in Canaanite jars, and amber in large quantities from the south Baltic coasts. Indeed, evidence of long-distance travel and trading (Mörner \& Lind, 2015).

\section{Conclusion about The Mjövik Calendar}

We turned an assumed golden bowl up-side-down (Figure 2) and found a sky dome (Figure 3) with ornamentation of solar-lunar astronomy that can be di- 
rectly connected with ancient astronomical-mathematical understanding developed by the Sumerians (Figure 4). The rock-carving at Backa (Figure 5) has a 6-spoked sun-symbol and a solar-lunar combination which must have been a central mystery for ancient people of how to measure a year. This means that we can put the Mjövik Sky Dome Calendar into an astronomical-religious context that spread from Mesopotamia to the Middle East and Europe during the Bronze Age (Figure 1).

This makes the Mjövik Calendar another remarkable ancient astronomical object in Europe, like the Trundholm Sun Chariot (Müller, 1903) and the Nebra Sky Disk (Welle, 2002).

\section{Acknowledgements}

We are indebted to Pamela Matlack-Klein (USA) for linguistic correction, Conny Klang (Sweden) for communication assistance, and Erkan Asanovski for taking pictures at the Bodrum Marine Museum in Turkey, with special permission to do so.

Author Contributions: N.A.M. turned the proposed bowl up-side-down and discovered that it, in fact, was a sky dome. B.G.L. identified the sexagesimal system and undertook extensive investigations of background material in Mesopotamia, Egypt, Middle East and Europe. G.H. checked all the ancient astronomical data, and verified them. N.A.M. wrote up the paper.

There is no competing interest either financial or scientific.

\section{References}

Baltzer, L. (1911). Hällristningar Från Bohuslän. Stockholm: Kungl. Vitterhetsakademin.

Henriksson, G. (1999). Prehistoric Constellations on Swedish rock-Carvings. In A. Le

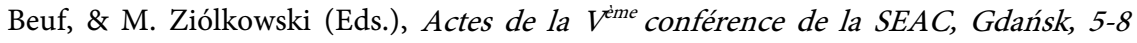
Septembre 1997 (pp 155-173). Warsaw.

Henriksson, G. (2017). The Acceleration of the Moon and the Universe: The Mass of Gravitation. Advances in Astrophysics, 2, 184-196. https://doi.org/10.22606/adap.2017.23004

Ifrah, G. (1994). Histoire Universelle des Chiffes. Bouquins: Robert Laffont.

Lind, B. G. (2005). Ales stenar som solkalendarium. Ale, 4, 21-24.

Lind, B. G., \& Mörner, N.-A. (2010). Mykenska och Feniciska spår på Österlen. Malmö: Stjärnljusets Förlag.

Montelius, O. (1911). Solguden och hans dyrkan. Nordisk Tidskrift, 1911, 1-26.

Mörner, N. A. (2015). Ales Stones in SE Sweden: A Solar Calendar from the Late Bronze Age. Journal of Archaeological Science: Reports, 2, 437-448. https://doi.org/10.1016/j.jasrep.2015.04.002

Mörner, N.-A., \& Lind, B. G. (2010). A Mediterranean Trading Centre in Southeast Sweden. In S. P. Paraminipoulos (Ed.), The Atlantis Hypothesis: Commentary 2018 (pp. 685-699). Heliotopos Publ.

Mörner, N.-A., \& Lind, B. G. (2012). Stonhenge Has Got a Younger Sister. Ales Stones Decoded. International Journal of Astronomy and Astrophysics, 2, 23-27. https://doi.org/10.4236/ijaa.2012.21004 
Mörner, N.-A., \& Lind, B. G. (2013). The Bronze Age in Sweden-Evidence of Long-Distance Travel and Advanced Sun Cult. Journal of Geography and Geology, 5, 78-91. https://doi.org/10.5539/jgg.v5n1p78

Mörner, N.-A., \& Lind, B. G. (2015). Long-Distance Travel and Trading in the Bronze Age: The East Mediterranean-Scandinavian ca. Archaeological Discovery, 3, 129-139. https://doi.org/10.4236/ad.2015.34012

Müller, S. (1903). Solvognen fra Trundholm. Nordiske Forntidsminder, 1, 16.

Oppert, J. (1876). Expédition Scientifique en Mésopotamie (1859-1863). Paris: Imprimerie Imporiale.

Pulak, C. (1998). The Uluburun Shipwreck: An Overview. International Journal of Nautical Archaeology, 27, 188-224. https://doi.org/10.1111/j.1095-9270.1998.tb00803.x

Rice, P. C. (1993). Amber Golden Gem of Ages. New York, NY: The Koscinszko Foundation.

SHM (2017). Föremål 109159. SHM 1426.

http://mis.historiska.se/mis/sok/fid.asp?fid=109159

Sippar (2017). https://en.wikipedia.org/wiki/Sippar

Von der Osten, H. (1934). Ancient Oriental Seals in the Collection of Mr. Edward T. Newell (p. 22). Chicago, IL: University Chicago Oriental Inst., Publ.

Welle, D. (2002). The Sky Disk of Nebra.

https://www.bibliotecapleyades.net/arqueologia/nebra_disk.htm 